\title{
Aleksandra Puzyniak
}

\section{Status prawny mniejszości narodowych w Republice Słowackiej}

\begin{abstract}
Abstrakt
Położenie mniejszości narodowych na terenie Republiki Słowackiej regulują liczne akty prawne. Wśród nich znajdują się dokumenty przyjmowane na gruncie krajowym oraz rozwiązania o charakterze międzynarodowym. Celem niniejszego artykułu jest przedstawienie treści najważniejszych ustaw oraz dokumentów, które wpływają na położenie mniejszości narodowych na Słowacji, a także przybliżenie reakcji organizacji międzynarodowych na wprowadzane przez Bratysławę regulacje prawne.
\end{abstract}

Słowa kluczowe: Słowacja, mniejszości narodowe, ustawodawstwo, prawo międzynarodowe, umowy międzynarodowe

\section{Wprowadzenie}

Położenie mniejszości narodowych na terenie Republiki Słowackiej regulują liczne akty przyjmowane na gruncie krajowym, a do najważniejszych należą konstytucja, ustawa o używaniu języków mniejszości narodowych i ustawa o języku państwowym. Odniesienia do mniejszości narodowych możemy odnaleźć jeszcze w wielu innych aktach, jak choćby w ustawie o przeciwdziałaniu dyskryminacji, ustawie o wychowaniu i edukacji oraz ustawie o radiu i telewizji. Kwestia mniejszości poruszana jest także w umowach bilateralnych, czego przykładem może być umowa o dobrym sąsiedztwie i przyjaznej współpracy między Republiką Słowacką a Republiką Węgierską. Wpływ na sytuację prawną mniejszości na terenie Słowacji mają także organizacje międzynarodowe, do których należy Bratysława. W tym przypadku największe oddziaływanie mają Rada Europy, Unia Europejska, Inicjatywa Środkowoeuropejska oraz Organizacja Narodów Zjednoczonych. Na przestrzeni lat słowackie władze utworzyły również instytucje odpowiadające za działania na rzecz mniejszości narodowych, a wśród nich ważną funkcję pełni 
Pełnomocnik Rządu Republiki Słowackiej do spraw mniejszości narodowych. Celem niniejszego artykułu jest analiza aktów prawnych oraz instytucji regulujących status prawny mniejszości narodowych na terenie Słowacji. Publikacja ma również ukazać, iż kwestia mniejszości jest poruszana w wielu rozwiązaniach prawnych, a słowackie władze na przestrzeni lat rozwinęły system ochrony i wsparcia tych społeczności. Autorka posłużyła się przede wszystkim metodą instytucjonalno-prawną.

\section{Wewnętrzne rozwiązania prawne oraz instytucje}

Analizę rozwiązań legislacyjnych należy rozpocząć od słowackiej ustawy zasadniczej, która jest podstawowym aktem regulującym sytuację mniejszości narodowych. Konstytucja Republiki Słowackiej (Ústava Slovenskej republiky) została przyjęta 1 IX 1992 r. Odniesienia do mniejszości zostały zawarte w podrozdziale IV rozdziału II, zatytułowanym: „Prawa mniejszości narodowych i grup etnicznych", w artykułach 33 oraz 34. Zgodnie z zapisem w artykule 33, nikt nie może być dyskryminowany ze względu na pochodzenie narodowe lub etniczne: „Przynależność do jakiejkolwiek mniejszości narodowej lub grupy etnicznej nie może przynosić nikomu szkody"'. W kolejnym artykule wymieniono prawa, jakie przysługują członkom mniejszości: w ustępie 1 czytamy, iż mogą oni bez przeszkód podtrzymywać swoją kulturę, posługiwać się językiem ojczystym oraz gromadzić się w stowarzyszeniach:

Obywatelom tworzącym w Republice Słowackiej mniejszości narodowe lub grupy etniczne gwarantuje się wszechstronny rozwój, zwłaszcza prawo rozwijania własnej kultury wspólnie z innymi członkami mniejszości albo grupy, prawo propagowania i otrzymywania informacji w ojczystym języku, organizowania się w narodowościowych towarzystwach, zakładania i utrzymywania instytucji oświatowych i kulturalnych $(\ldots)^{2}$.

W kolejnym ustępie ustawodawca przyznaje członkom mniejszości prawo do nauczania we własnym języku, posługiwania się nim w kontaktach urzędowych oraz prawo do uczestniczenia w rozwiązywaniu dotyczących ich spraw. W ustępie 3 zaznaczono jednakże, że realizowanie tych praw nie może „prowadzić do zagrożenia suwerenności i jedności terytorialnej Republiki Słowackiej oraz dyskryminacji innych obywateli"3. Odniesienia do mniejszości narodowych zostały

1 Konstytucja Republiki Słowackiej, tłumaczenie K. Skotnicki, http://biblioteka.sejm.gov.pl/ wp-content/uploads/2016/11/Slowacja_pol_010711.pdf (30 XII 2020), s. 700.

2 Ibidem.

$3 \quad$ Ibidem, s. 700. 
zawarte także w artykule 12, w ustępie 2 oraz 3 . W pierwszym z nich czytamy, iż zakazuje się dyskryminacji osób m.in. ze względu na pochodzenie narodowe, przynależność do narodowości lub grupy etnicznej, zaś w ustępie 3 ustawodawca zezwala na samodzielne decydowanie o swojej narodowości ${ }^{4}$.

Drugim, niezwykle ważnym dokumentem regulującym status mniejszości narodowych na terenie Słowacji jest ustawa o używaniu języków mniejszości narodowych z 1999 r. (Zákon o používaní jazykov národnostných menšín). Ustawa była dwukrotnie nowelizowana (2009 oraz 2011 r.), a w obecnym kształcie obowiązuje od 15 V 2011 r. ${ }^{5}$. Dokument rozpoczyna się od podania definicji języka mniejszości narodowych oraz ich wymienieniu (artykuł 1, ustęp 2): „(...) język mniejszości oznacza język skodyfikowany lub znormalizowany tradycyjnie używany na terytorium Republiki Słowackiej przez jej obywateli należących do mniejszości narodowej i który różni się od języka państwowego; językiem mniejszości jest bułgarski, czeski, chorwacki, węgierski, niemiecki, polski, romski, rusiński i ukraiński”'. Bardzo ważny jest artykuł 2, gdyż przedstawiono w nim zasady posługiwania się językiem mniejszości w kontaktach urzędowych. Zgodnie z zapisem język mniejszości może stać się drugim językiem urzędowym w danej gminie, jeśli odsetek mieszkańców wynosi 15\% „według dwóch kolejnych spisów powszechnych" ". Jak zauważają Radosław Zenderowski i Piotr Bajda, próg ten został obniżony po nowelizacji ustawy, ponieważ w poprzedniej wersji wynosił $20 \%{ }^{8}$. Jednocześnie może dojść do sytuacji, w której język mniejszości utraci ów status jest to możliwe, gdy liczba członków mniejszości w danej gminie spadnie poniżej $15 \%$ i potwierdzą to trzy kolejne spisy powszechne9. Ustawa reguluje także kwestię nazewnictwa w języku mniejszości. W artykule 4 ustępie 2 ustawodawca zezwala na umieszczanie nazw gmin i miejscowości w języku mniejszości obok nazwy w języku państwowym. Język mniejszości może być wprowadzony także na budynkach dworców autobusowych, kolejowych, lotniskach (ustęp 3) oraz w nazwach ulic (ustęp 4). Oprócz tego „w wydawnictwach naukowych, prasie i innych środkach masowego przekazu oraz w oficjalnych działaniach organów administracji publicznej, jeżeli posługują się językiem mniejszości, obok ujednoliconych nazw geograficznych można umieszczać nazwy obiektów geograficznych, które są dobrze znane i zakorzenione w języku mniejszości” (ustęp 5). W języku

Ibidem, s. 696.

R. Zenderowski, P. Bajda, Polityka etniczna Słowacji, [w:] Polityka etniczna współczesnych państw Europy Środkowo-Wschodniej, red. H. Chałupczak, R. Zenderowski, W. Baluk, Lublin 2015, s. 450.

6 Zákon z 10. júla 1999 o používaní jazykov národnostných menšín, https://www.slov-lex.sk/ pravne-predpisy/SK/ZZ/1999/184/ (1 I 2021).

Ibidem.

$8 \quad$ R. Zenderowski, P. Bajda, op.cit., s. 451.

9 Ibidem. 
mniejszości mogą być również podawane wszelkie ogłoszenia „mające na celu informowanie opinii publicznej, w szczególności w sklepach, obiektach sportowych, restauracjach, na ulicach, na i nad drogami, na lotniskach, dworcach autobusowych i dworcach kolejowych" (ustęp 6) ${ }^{10}$. Ważny dla członków mniejszości jest ustęp 7 artykułu 4, w którym ustawodawca zezwala na umieszczanie napisów na pomnikach oraz tablicach pamiątkowych w języku mniejszości. Język mniejszości może być również użyty w wydaniach okolicznościowych przygotowanych przez muzea, biblioteki, galerie oraz podczas wszelkich wydarzeń kulturalnych (artykuł 5a, ustęp 3) ${ }^{11}$. Ponadto ustawa zobowiązuje Biuro Rządowe Republiki do przedkładania rządowi Słowacji raportu o stanie używania języków mniejszości narodowych. Raport opiniowany jest przez Radę Rządu Republiki Słowackiej ds. Praw Człowieka, Mniejszości Narodowych i Równości Płci. W ustawie czytamy również, że kwestie nazewnictwa gmin w językach mniejszości, posługiwania się nimi w postępowaniach sądowych oraz nadawania programów radiowych i telewizyjnych w tych językach regulują odrębne akty prawne.

Kolejnym wartym omówienia przykładem rozwiązań legislacyjnych jest ustawa w sprawie równego traktowania w niektórych obszarach oraz w sprawie ochrony przed dyskryminacją oraz zmianie niektórych ustaw, zwana też ustawą antydyskryminacyjną (Zákon o rovnakom zaobchádzaní v niektorých oblastiach a o ochrane pred diskrimináciou a o zmene a doplnení niektorých zákonov (antidiskriminačný zákon) z 20 V 2004 r. W aktualnej wersji obowiązuje od 2 I 2016 r. W artykule 2 ustępie 1 wyjaśniono, czym jest równe traktowanie: „Przestrzeganie zasady równego traktowania polega na zakazie dyskryminacji ze względu na płeć, religię lub światopogląd, rasę, narodowość lub grupę etniczną, niepełnosprawność, wiek, orientację seksualną, stan cywilny lub rodzinny, kolor skóry, język, przekonania polityczne, narodowość (...)"12. W ustępie 3 dodano, że równe traktowanie to także podejmowanie działań zabezpieczających przed dyskryminacją. Bezpośrednie odniesienia do przedstawicieli mniejszości zostały zawarte $\mathrm{w}$ artykule 8a, w którym ustawodawca wymienia tymczasowe środki wyrównawcze oraz określa okoliczności ich zastosowania. W ustępie pierwszym wymieniono cele zastosowania tychże środków: wyeliminowanie niekorzystnych warunków społecznych lub ekonomicznych, promowanie ich interesów m.in. poprzez kulturę i edukację oraz zapewnienie równego dostępu do szkolnictwa, zatrudnienia oraz opieki zdrowotnej. Środki te mogą być wprowadzone do czasu aż dana nierówność zaniknie, zaś władze publiczne „są zobowiązane do ciągłego monitorowania, oceny i publikowania przyjętych tymczasowych środków wyrównawczych w celu

\footnotetext{
Zákon z 10. júla 1999 o používaní..., op.cit.

Ibidem.

2 Zákon z 20. mája 2004 o rovnakom zaobchádzaní v niektorých oblastiach a o ochrane pred diskrimináciou a o zmene a doplnení niektorých zákonov (antidiskriminačný zákon), https:// www.slov-lex.sk/pravne-predpisy/SK/ZZ/2004/365/20160102 (5 II 2021).
} 
ponownej oceny uzasadnienia ich dalszego obowiązywania oraz do poinformowania Słowackiego Narodowego Centrum Praw Człowieka o tych faktach"13.

Następnym dokumentem jest ustawa o nazwach gmin w językach mniejszości narodowych (Zákon o označovaní obcí v jazyku národnostných menšín) z lipca 1994 r. Jak dotąd ustawa była nowelizowana tylko raz w 2009 r. W artykule 1 ustępie 1 czytamy: „Gminy, w których członkowie mniejszości narodowej stanowią co najmniej $20 \%$ ludności (...) są oznaczane w języku mniejszości narodowej na oddzielnych znakach drogowych wskazujących początek gminy i jej koniec"14. Kolejny ustęp precyzuje, jak ma wyglądać owe oznakowanie: „Znaki drogowe, o których mowa w ust. 1, umieszcza się pod znakami drogowymi z nazwą gminy, która jest zawsze podawana w języku państwowym”. Za opracowanie znaków odpowiada Ministerstwo Spraw Wewnętrznych (artykuł 1 ustęp 4). Ustawa zawiera również załącznik z listą gmin, które można zapisywać w języku mniejszości narodowych. Co istotne, zdecydowana większość jest zapisana w języku węgierskim. Ważna zmiana w ustawie została dokonana w 2011 r. - wówczas zniesiono zasadę posługiwania się językiem słowackim w kontaktach urzędowych, a regulował to artykuł 2: „W komunikacji urzędowej, zwłaszcza na dokumentach urzędowych, pieczęciach gmin, pracach kartograficznych oraz w komunikacji pocztowej, nazwy gmin są używane wyłącznie w języku państwowym" ${ }^{15}$. Niezwykle istotny jest również artykuł 3, zgodnie z którym mieszkańcy gminy mogą dokonać zmiany jej niesłowackiej nazwy na inną niesłowacką. Ustęp 2 artykułu 3 precyzuje, kiedy taka zmiana jest możliwa: „Głosowanie na podstawie ust. 1 jest ważne, jeżeli wzięła w nim udział bezwzględna większość mieszkańców gminy uprawnionych do głosowania na podstawie odrębnego zarządzenia. Decyzję gminy na podstawie ust. 1 podejmuje się, jeżeli co najmniej $80 \%$ mieszkańców gminy, którzy wzięli udział w głosowaniu, oddało ważny głos za jej przyjęciem" ${ }^{16}$. Przepisy te nie dotyczą jednak gmin, których nazwa została zmieniona w latach 1867-1918 oraz 1938-1945.

Ustawa o języku państwowym Republiki Słowackiej (Zákon Národnej rady Slovenskej republiky o štátnom jazyku Slovenskej republiky) jest kolejną regulacją prawną, która istotnie wpływa na położenie mniejszości na terenie kraju. Ustawa była wielokrotnie zmieniana: po raz pierwszy w 1997 r., dwukrotnie w 1999 r., w 2007 r. oraz dwukrotnie w 2009 r. ${ }^{17}$. W artykule pierwszym zaznaczono, iż język słowacki jest językiem państwowym na terytorium kraju oraz posiada pierwszeństwo przed innymi językami (odpowiednio ustępy 1 i 2). Ustawodawca dopuszcza

\footnotetext{
13 Ibidem.

14 Zákon o označovaní obcí v jazyku národnostných menšín, https://www.zakonypreludi.sk/zz/ 1994-191 (12 V 2021).

15 P. Bajda, R. Zenderowski, Polityka etniczna Słowacji, Warszawa 2016, s. 143.

16 Zákon o označovaní obcí..., op.cit.

17 P. Bajda, R. Zenderowski, op.cit., s. 144.
} 
jednakże stosowanie języków mniejszości narodowych w wybranych obszarach. Jest to możliwe w audycjach „przeznaczonych dla nieletnich dzieci poniżej 12 roku życia" (artykuł 5 ustęp 2), w okazjonalnych publikacjach kulturalnych, katalogach galerii, muzeów, bibliotek oraz podczas wydarzeń kulturalno-edukacyjnych (artykuł 5 ustęp 6 i 7) ${ }^{18}$. Zgodnie z artykułem 8 ustępem 4, członkowie mniejszości narodowych mogą posługiwać się swoim językiem „w porozumiewaniu się z personelem tych placówek [medycznych i socjalnych] w gminach, w których język mniejszości narodowej jest używany w oficjalnej komunikacji zgodnie ze specjalnym przepisem" 19 .

Odniesienia do mniejszości narodowych zostały zawarte również w ustawie o radiu i telewizji Słowacji (Zákon o Rozhlase a televízii Slovenska) z grudnia $2010 \mathrm{r}$. W artykule 1 ustępie 1, podpunkcie b) ustawodawca wymienia, iż jednym z głównych zadań radia i telewizji Słowacji jest „nadawanie co najmniej czterech programów radiowych, z których jeden jest przeznaczony do nadawania treści i programów zrównoważonych regionalnie w językach mniejszości narodowych i grup etnicznych zamieszkujących terytorium Republiki Słowackiej (...)"20. W podpunkcie g) dodaje jeszcze, iż zadaniem mediów słowackich jest „nadawanie treści i programów zrównoważonych regionalnie w językach mniejszości narodowych i grup etnicznych zamieszkujących terytorium Republiki Słowackiej w przedziale czasowym odpowiadającym narodowemu i etnicznemu składowi ludności Republiki Słowackiej; aby zapewnić produkcję i nadawanie programów dla mniejszości narodowych i grup etnicznych, Słowackie Radio i Telewizja ustanawia oddzielne jednostki organizacyjne Słowackiego Radia i Słowackiej Telewizji”21.

Kwestia mniejszości została poruszona w ustawie o wychowaniu i kształceniu (ustawa szkolna) - Zákon o výchove a vzdelávaní (školský zákon). Dokument wszedł w życie 1 IX 2008 r. W artykule 11 zatytułowanym „Dokumentacja pedagogiczna i inna dokumentacja”, w ustępie 2 czytamy, iż ustawodawca zezwala na prowadzenie dokumentacji pedagogicznej w szkołach należących do mniejszości w dwóch językach, tj. państwowym i w języku danej mniejszości: „(...) W szkołach i placówkach szkolnych objętych ustawą, w których kształcenie i szkolenie prowadzone jest w języku mniejszości narodowych, dokumentacja pedagogiczna szkoły jest prowadzona dwujęzycznie, w języku państwowym oraz w języku odpowiedniej mniejszości narodowej”22. W artykule 12 pt. „Język edukacji”, w ustępie 3

18 Zákon Národnej rady Slovenskej republiky o štátnom jazyku Slovenskej republiky, https://www. zakonypreludi.sk/zz/1995-270 (17 V 2021).

19 Ibidem.

20 Zákon o Rozhlase a televízii Slovenska, https://www.zakonypreludi.sk/zz/2010-532 (25 V 2021).

21 Ibidem.

22 Zákon o výchove a vzdelávaní (školský zákon) a o zmene a doplnení niektorých zákonov, https:// www.slov-lex.sk/pravne-predpisy/SK/ZZ/2008/245/ (3 VI 2021). 
mowa jest o nauczaniu w języku mniejszości narodowych: „Dzieciom i uczniom obywateli należących do mniejszości narodowych i grup etnicznych gwarantuje się, poza prawem do nauki języka państwowego, prawo do wychowania i nauki w ich języku na warunkach określonych w niniejszej ustawie"23. W ustępie 5 szczegółowo opisano zasady tegoż nauczania: edukacja w języku mniejszości odbywa się: „a) w szkołach i klasach, w których kształcenie i szkolenie jest prowadzone w języku odpowiedniej mniejszości narodowej; b) w szkołach i salach lekcyjnych, gdzie jednym z przedmiotów jest język mniejszości narodowej, a językiem wykładowym pozostałych przedmiotów jest język państwowy; w tych szkołach i klasach niektóre przedmioty mogą być nauczane w języku mniejszości narodowej, w szczególności plastyka, wychowanie muzyczne, wychowanie fizyczne (...)"24.

Pozostałe ustawy, które regulują status i położenie mniejszości narodowych na terenie Słowacji to:

a) Ustawa o postępowaniu administracyjnym z 1967 r. (Zákon o správnom konaní (správny poriadok);

b) Ustawa w sprawie stowarzyszenia obywateli z 1990 r. (Zákon o združovaní občanov);

c) Ustawa o przestępczości z 1990 r. (Zákon o priestupkoch);

d) Ustawa w sprawie wolności wyznania oraz statusu kościołów i związków wyznaniowych z $1991 \mathrm{r}$. (Zákon o slobode náboženskej viery a postavení cirkví a náboženských spoločnostî);

e) Ustawa o imieniu i nazwisku z 1993 r. (Zákon o mene a priezvisku);

f) Ustawa w sprawie utworzenia Słowackiego Krajowego Centrum Praw Człowieka z 1993 r. (Zákon o zriadení Slovenského národného strediska pre ludské práva);

g) Ustawa o rejestrach z 1994 r. (Zákon o matrikách);

h) Ustawa o swobodnym dostępie do informacji oraz zmianie niektórych ustaw (ustawa o wolności informacji) z 2000 r. (Zákon o slobodnom prístupe k informáciám a o zmene a doplnení niektorých zákonov (zákon o slobode informácií));

i) Ustawa w sprawie Publicznego Obrońcy Praw z 2001 r. (Zákon o verejnom ochrancovi práv);

j) Ustawa w sprawie organizacji działań rządu i organizacji centralnej administracji państwowej z 2001 r. (Zákon o organizácii činnosti vlády a organizácii ústrednej štátnej správy);

k) Rozporządzenie rządowe określające szczegółowy podział środków z budżetu państwa na szkoły i placówki szkolne z 2008 r. (Nariadenie vlády

3 Ibidem.

24 Ibidem. 
ktorým sa ustanovujú podrobnosti rozpisu finančných prostriedkov zo štátneho rozpočtu pre školy a školské zariadenia);

1) Ustawa o administracji państwowej w oświacie i samorządzie szkolnym oraz o zmianie niektórych ustaw z 2003 r. (Zákon o štátnej správe v školstve a školskej samospráve a o zmene a doplnení niektorých zákonov);

ł) Ustawa w sprawie finansowania szkół podstawowych, gimnazjów i obiektów szkolnych z 2003 r. (Zákon o financovaní základných škôl, stredných škôl a školských zariadení);

m) Ustawa o opiece zdrowotnej, usługach związanych ze świadczeniem opieki zdrowotnej oraz o zmianie niektórych ustaw z 2004 r. (Zákon o zdravotnej starostlivosti, službách súvisiacich s poskytovaním zdravotnej starostlivosti a o zmene a doplnení niektorých zákonov);

n) Ustawa w sprawie cyfrowego rozpowszechniania programów i świadczenia innych usług w zakresie treści drogą transmisji cyfrowej oraz o zmianie niektórych ustaw (ustawa o radiofonii i telewizji) z 2007 r. (Zákon o digitálnom vysielaní programových služieb a poskytovaní iných obsahových služieb prostredníctvom digitálneho prenosu a o zmene a doplnení niektorých zákonov (zákon o digitálnom vysielaní));

o) Ustawa o Agencji Prasowej Republiki Słowackiej oraz o zmianie niektórych ustaw z 2008 r. (Zákon o Tlačovej agentúre Slovenskej republiky a o zmene niektorých zákonov);

p) Dekret Ministerstwa Spraw Wewnętrznych Republiki Słowackiej z dnia 20 XII 2008 r. implementacja ustawy o ruchu drogowym oraz o zmianie niektórych ustaw (Vyhláška Ministerstva vnútra Slovenskej republiky z 20. decembra 2008, ktorou sa vykonáva zákon o cestnej premávke a o zmene a doplnení niektorých zákonov);

q) Ustawa o kolei i o zmianie niektórych ustaw z 2009 r. (Zákon o dráhach a o zmene a doplnení niektorých zákonov);

r) Ustawa o warunkach wykonywania prawa głosu oraz o zmianie niektórych ustaw z 2014 r. (Zákon o podmienkach výkonu volebného práva a o zmene a doplnení niektorých zákonov);

s) Ustawa o bibliotekach oraz o zmianie ustawy nr 206/2009 Dz. o muzeach i galeriach oraz o ochronie dóbr kultury i o nowelizacji ustawy Słowackiej Rady Narodowej nr 372/1990 Dz. o wykroczeniach w brzmieniu późniejszych przepisów zmienionymi ustawą nr 38/2014 Zb z 2015 r. (Zákon o knižniciach a o zmene a doplnení zákona č. 206/2009 Z. z. o múzeách a o galériách a o ochrane predmetov kultúrnej hodnoty a o zmene zákona Slovenskej národnej rady č. 372/1990 Zb. o priestupkoch $v$ znení neskorších predpisov v znení zákona č. 38/2014 Z.z);

t) (Ustawa) kodeks postępowania cywilnego z 2015 r. (Zákon civilnýsporový poriadok); 
u) Kodeks postępowania administracyjnego z 2015 r. (Správny súdny poriadok);

v) Dekret Biura Rządu Republiki Słowackiej z dnia 19 V 2017 r. określający szczegóły szkolenia urzędników służby cywilnej (Vyhláška Úradu vlády Slovenskej republiky z 19. mája 2017, ktorou sa ustanovujú podrobnosti o vzdelávaní štátnych zamestnancov);

w) Ustawa o Funduszu Wspierania Kultury Mniejszości Narodowych oraz o zmianie niektórych ustaw z 2017 r. (Zákon o Fonde na podporu kultúry národnostných menšín a o zmene a doplnení niektorých zákonov);

x) Ustawa o Sądzie Konstytucyjnym Republiki Słowackiej oraz o zmianie niektórych ustaw z 2018 r. (Zákon o Ústavnom súde Slovenskej republiky a o zmene a doplnení niektorých zákonov).

$\mathrm{Na}$ przestrzeni lat słowackie władze powołały do życia kilka instytucji oraz organizacji odpowiedzialnych za działania na rzecz mniejszości narodowych i etnicznych. Ich głównym celem jest wspomaganie administracji państwowej w ochronie praw tych społeczności przez monitorowanie ich sytuacji prawnej, doradztwo w przyjmowaniu nowych rozwiązań prawnych oraz szeroko pojmowane wspieranie ich działalności. Opis powyższych instytucji należy rozpocząć od przybliżenia działalności Pełnomocnika Rządu Republiki Słowackiej do Spraw Mniejszości Narodowych (Splnomocnenec vlády Slovenskej republiky pre národnostné menšiny). Funkcja Pełnomocnika została utworzona w 2012 r. i zastąpiła urząd wicepremiera ds. integracji europejskiej, praw człowieka i mniejszości ${ }^{25}$. Zgodnie ze statutem, Pełnomocnik jest powoływany przez rząd na wniosek premiera. Jego zadaniem jest ochrona, rozwój oraz wspieranie „praw osób należących do mniejszości narodowych” oraz przeprowadzanie działań, których celem jest poprawa ich położenia ${ }^{26}$. Ponadto „monitoruje, analizuje i ocenia przestrzeganie praw osób należących do mniejszości narodowych przez organy administracji państwowej, samorządu terytorialnego i inne właściwe podmioty" i co dwa lata przedstawia rządowi raport o stanie oraz prawach osób należących do mniejszości ${ }^{27}$. Co ciekawe, raport jest przygotowywany tylko w dwóch językach: słowackim i angielskim. Pełnomocnik może także przygotowywać opinie na temat istniejących regulacji prawnych lub tworzyć własne propozycje rozwiązań legislacyjnych i nielegislacyjnych dotyczących mniejszości. Jego zadaniem jest również działanie na rzecz poprawy systemu edukacji dla mniejszości. Ponadto

25 Urząd wicepremiera ds. integracji europejskiej, praw człowieka i mniejszości został utworzony w 2002 r., a jednym z zadań wicepremiera było m.in. koordynowanie działań Sekcji Praw Człowieka oraz Mniejszości. R. Zenderowski, P. Bajda, Polityka etniczna Słowacji, [w:] Polityka etniczna..., op.cit., s. 453.

26 Štatút splnomocnenca vlády SR pre národnostné menšiny, https://www.narodnostnemensiny. gov.sk//statut-splnomocnenca-vlady-sr-pre-narodnostne-mensiny/ (6 VI 2021).

27 Ibidem. 
Pełnomocnik stara się poprawić nauczanie języka słowackiego wśród tych społeczności. Należy podkreślić, iż Pełnomocnik współpracuje nie tylko z rządem, ale także $\mathrm{z}$ „organami (...) samorządu terytorialnego oraz $\mathrm{z}$ organizacjami pozarządowymi i innymi podmiotami”28.

Kolejnym przejawem działalności słowackich władz na rzecz mniejszości narodowych jest Fundusz Wspierania Kultury Mniejszości Narodowych (Fond na podporu kultury národnostných menšín). Fundusz został powołany na mocy ustawy w 2017 r. Jest to niezależna instytucja publiczna, której celem jest „wspieranie i animowanie kultury mniejszości narodowych"29. Do głównych zadań Funduszu należy: dbanie o rozwój działalności kulturalnej i edukacyjnej mniejszości narodowych, wspieranie dialogu międzykulturowego, tworzenie warunków do zachowywania oraz wyrażania tożsamości narodowej i kulturowej przedstawicielom mniejszości narodowych, promowanie edukacji i szkoleń w zakresie praw mniejszości narodowych, a także udzielanie wsparcia finansowego ( $\mathrm{w}$ formie grantów lub stypendiów) dla działalności kulturalnej i edukacyjnej tychże społeczności ${ }^{30}$. W działalność Funduszu włączeni są przedstawiciele mniejszości poprzez członkostwo w Radzie Ekspertów, a na czele instytucji stoi dyrektor. Fundusz współpracuje z organami administracji państwowej i samorządu terytorialnego, instytucjami publicznymi oraz organizacjami partnerskimi poza granicami kraju. Jak podkreślono w statucie, swoją działalnością Fundusz realizuje politykę kulturalną Republiki Słowackiej oraz wpisuje się w działalność Unii Europejskiej w zakresie wspierania rozwoju mniejszości narodowych.

Następnym przykładem instytucji jest powołana w 1999 r. Rada Rządu Republiki Słowackiej ds. Praw Człowieka, Mniejszości Narodowych i Równości Płci (Rada vlády Slovenskej republiky pre ludské práva, národnostné menšiny a rodovú rovnost'). Rada jest organem stałym o charakterze doradczym i koordynacyjnym rządu, a jej podstawowym celem jest ochrona praw i wolności człowieka, praw politycznych i obywatelskich oraz praw osób należących do mniejszości, w tym do mniejszości narodowych. Do zadań Rady należy wydawanie opinii na temat wykonywania przez rząd Słowacji międzynarodowych zobowiązań prawnych w obszarze ochrony praw człowieka. Przewodniczącym Rady jest minister sprawiedliwości, a wiceprzewodniczącymi są minister pracy, spraw społecznych i rodziny, minister edukacji, nauki, badań naukowych i sportu, minister kultury, sekretarz stanu ministerstwa sprawiedliwości oraz przedstawiciel społeczeństwa obywatelskiego. Sekretarzem Rady jest Dyrektor Departamentu Praw Człowieka Sekcji Legislacyjnej Ministerstwa Sprawiedliwości Republiki Słowackiej. W skład

28 Ibidem.

29 Fond na podporu kultúry národnostných menšín, https://www.kultminor.sk/sk/fond/charakteristika-fondu (13 VII 2021).

30 Štatút Fondu na podporu kultúry národnostných menšin, https://www.kultminor.sk/attachments/article/405/Statut_FPKNM.pdf (13 VII 2021). 
instytucji wchodzi siedem stałych komisji, w tym Komisja ds. Mniejszości Narodowych i Grup Etnicznych ${ }^{31}$.

Następnym przykładem organu, który wpływa na politykę etniczną Republiki jest Słowackie Narodowe Centrum Praw Człowieka (Slovenské národné stredisko pre ludské práva). Centrum zostało utworzone w 1993 r. i jest niezależną instytucją z dwoma mandatami: Krajową Instytucją Praw Człowieka i Krajowym Organem Antydyskryminacyjnym. Słowackie Narodowe Centrum powstało na mocy porozumienia między ONZ a Bratysławą „w celu monitorowania i badania naruszeń praw człowieka i podnoszenia świadomości roli praw człowieka w społeczeństwie demokratycznym"32. Centrum raz w roku publikuje Raport o Prawach Człowieka, w którym informuje, czy słowacki rząd wywiązuje się z międzynarodowych zobowiązań. Zadaniem Słowackiego Narodowego Centrum jest również prowadzenie kampanii informacyjnych na temat przestrzegania praw człowieka i równego traktowania, a także prowadzenie badań i ankiet w tym zakresie ${ }^{33}$.

\section{Rozwiązania międzynarodowe - umowy bilateralne i multilateralne}

Sytuację prawną mniejszości narodowych na terenie Republiki Słowackiej regulują także umowy międzynarodowe bilateralne oraz multilateralne. Analizę tychże warto rozpocząć od umowy o dobrym sąsiedztwie i przyjaznej współpracy między Republiką Węgierską a Republiką Słowacką (Zmluva o dobrom susedstve a priatel'skej spolupráci medzi Madiarskou republikou a Slovenskou republikou). Spośród wszystkich traktatów o dobrym sąsiedztwie i przyjaznej współpracy zawartych przez Bratysławę, umowa z Budapesztem była najdłużej negocjowana, a kwestia mniejszości została w nim najobszerniej opisana. Umowa została podpisana 19 III 1995 r. w Paryżu i weszła w życie w maju 1996 r. O tym, jak ważna dla obu stron była problematyka mniejszości narodowych świadczy odniesienie się do niej już w preambule dokumentu:

(...) uznając, że osoby należące do mniejszości narodowych stanowią integralną część społeczeństwa i państwa Umawiającej się Strony, na której terytorium żyją, a jednocześnie przyczyniają się do wzbogacenia jej życia oraz pogłębienia zaufania, przyjaźni i współpracy między ich państwami i deklarując swoją odpowiedzialność za: zapewnienie ochrony oraz pomoc w zachowaniu i pogłębianiu

31 Rada vlády SR pre ludské práva, národnostné menšiny a rodovú rovnost', https://www.radavladylp.gov.sk/ (14 VII 2021).

32 Slovenské národné stredisko pre ludské práva, http://www.snslp.sk/o-nas/o-stredisku/ (14 VII 2021).

33 Ibidem. 
tożsamości narodowej lub etnicznej, kulturowej, religijnej i językowej mniejszości zamieszkujących ich terytorium, Potwierdzając, że kierują się zasadami zapisanymi w Karcie Narodów Zjednoczonych, Akcie końcowym Konferencji Bezpieczeństwa i Współpracy w Europie z Helsinek, Paryskiej Karcie Nowej Europy Konferencji Bezpieczeństwa i Współpracy w Europie oraz w innych dokumentach przyjętych przez Organizację Bezpieczeństwa i Współpracy w Europie, Przekonane, że dalszy rozwój przyjaznych stosunków i współpracy na nowych podstawach między nimi leży w żywotnym interesie ich krajów i narodów $(. . .)^{34}$.

Do kwestii mniejszości narodowych odniesiono się w artykule 15. Należy zaznaczyć, iż jest to najobszerniejszy artykuł tej umowy. W ustępie pierwszym podkreślono, że ochrona osób należących do mniejszości narodowych „stanowi integralną część międzynarodowej ochrony praw człowieka”, zaś współpraca w tym obszarze wpływa na rozwój dobrych stosunków, budowania zaufania, „przy jednoczesnym umacnianiu bezpieczeństwa międzynarodowego, stabilności i integracji europejskiej” ${ }^{35}$. W ustępie drugim władze Słowacji i Węgier zobowiązały się do prowadzenia antydyskryminacyjnej polityki, zapewnienia swobody w decydowaniu o przynależności narodowej oraz rozwoju kultury i tradycji osób należących do mniejszości. Strony zadeklarowały, iż nie będą prowadziły polityki asymilacyjnej na swoim terytorium oraz zapewniły członkom mniejszości prawo do „tworzenia i utrzymywania własnych organizacji, stowarzyszeń, w tym partii politycznych, a także instytucji oświatowych, kulturalnych i religijnych, w ramach odpowiednich ram prawnych, w celu kultywowania, rozwijania i przeniesienie ich tożsamości”. Oprócz tego członkowie mniejszości zyskali prawo do aktywnego udziału w decyzjach odnoszących się do mniejszości narodowych lub do obszaru, na którym występują. Władze obu państw zapewniły tym grupom prawo do posługiwania się ojczystym językiem w kontaktach urzędowych, szkolnictwie, w pisowni imion i nazwisk, nazwach gmin, miejscowości oraz ulic. W kolejnym podpunkcie h), strony zobowiązały się do stworzenia warunków do utrzymania i zachowania obiektów architektonicznych oraz pomników stanowiących element kultury oraz historii mniejszości. W ustępie 4 rządzący podkreślili, iż będą „stosować normy i zobowiązania polityczne przewidziane w następujących dokumentach jako zobowiązania prawne: Dokument ze spotkania w Kopenhadze Konferencji Bezpieczeństwa i Współpracy w Europie w sprawie Wymiaru Ludzkiego z dnia 29 VI 1990 r., Deklaracja Zgromadzenia Ogólnego Narodów Zjedno-

34 Zmluva o dobrom susedstve a priatel'skej spolupráci medzi Slovenskou republikou a Madiarskou republikou, https://www.aspi.sk/products/lawText/1/45399/1/2/oznamenie-c-115-1997-zz-o-uzavreti-zmluvy-o-dobrom-susedstve-a-priatelskej-spolupraci-medzi-slovenskou-republikou-a-madarskou-republikou/oznamenie-c-115-1997-zz-o-uzavreti-zmluvy-o-dobrom-susedstve-a-priatelskej-spolupraci-medzi-slovenskou-republikou-a-madarskou-republikou (22 VI 2021).

35 Ibidem. 
czonych nr 47/135 w sprawie praw osób należących do mniejszości narodowych lub etnicznych, religijnych i językowych, Zalecenie Zgromadzenia Parlamentarnego Rady Europy nr 1201 (1993), respektuje prawa jednostki i obywatela, w tym prawa osób należących do mniejszości narodowych"36. W ustępie 6 zobowiązano się do wzajemnej kontroli w wypełnianiu treści umowy. W tym celu zadecydowano o utworzeniu międzyrządowej wspólnej komisji z prawem rekomendacji.

Klauzula mniejszościowa została zawarta również w Układzie między Rzecząpospolitą Polską a Czeską i Słowacką Republiką Federacyjną o dobrym sąsiedztwie, solidarności i przyjacielskiej współpracy z 6 X $1991 \mathrm{r}$. W artykule 8 ustępie 1 strony umowy zapewniły członkom mniejszości prawo indywidualne i zbiorowe do „swobodnego wyrażania, zachowywania i rozwijania swej tożsamości etnicznej, kulturowej, językowej i religijnej (...)" oraz zobowiązały się, że nie będą prowadziły asymilacji tychże społeczności ${ }^{37}$. W kolejnym ustępie wymieniono prawa, jakie przysługują członkom mniejszości. Wśród nich znalazły się m.in.: swoboda posługiwania się językiem ojczystym w przestrzeni publicznej oraz prywatnej, dostęp do informacji oraz ich rozpowszechniania w języku ojczystym, możliwość nauczania oraz nauki w języku ojczystym, a także prawo do zakładania i prowadzenia własnych instytucji kulturowych, religijnych oraz stowarzyszeń. W ustępie 3 zapewniono, iż każdy ma prawo do samodzielnego określenia swojej przynależności narodowej i nie mogą z niej wynikać żadne negatywne konsekwencje. W ustępie 4 stwierdzono natomiast, że „przynależność do mniejszości narodowej nie zwalnia obywatela z obowiązku lojalnego postępowania wobec swego Państwa, przestrzegania jego przepisów prawnych i korzystania ze swoich praw zgodnie z prawem krajowym"38.

Rok później podpisano Umowę między Czeską i Słowacką Republiką Federacyjną a Republiką Federalną Niemiec o dobrym sąsiedztwie i przyjaznej wspólpracy (Zmluva medzi Českou a Slovenskou Federatívnou Republikou a Spolkovou republikou Nemecko a dobrom susedstve a a priatel'skej spolupráci). Zagadnieniom mniejszości zostały poświęcone dwa artykuły: artykuł 20 odnosi się do mniejszości niemieckiej, zaś artykuł 21 dotyczy mniejszości czeskiej oraz słowackiej. W ustępie 2 artykułu 20 społeczności niemieckiej zapewniono prawo indywidualne i zbiorowe do zachowania oraz rozwijania swojej kultury, tożsamości narodowej, językowej i religijnej „bez jakichkolwiek prób asymilacji wbrew ich woli”39.

36 Ibidem.

37 Układ między Rzeczapospolita Polska a Czeska i Słowacja Republika Federacyjna o dobrym sasiedztwie, solidarności i przyjacielskiej współpracy, http://isap.sejm.gov.pl/isap.nsf/download. xsp/WDU19920590296/O/D19920296.pdf (15 VII 2021). Ibidem.

39 Zmluva medzi Českou a Slovenskou Federatívnou Republikou a Spolkovou republikou Nemecko a dobrom susedstve a a priatel'skej spolupráci, https://www.aspi.sk/products/lawText/1/40295/ 1/2/sdeleni-c-521-1992-zb-o-zmluve-medzi-ceskou-a-slovenskou-federativnou-republikou- 
W ustępie trzecim podkreślono, że każdy ma prawo samodzielnie decydować o swojej przynależności narodowej i nie powinien ponosić z tego powodu negatywnych konsekwencji, a w ustępie 5 władze Republiki Federacyjnej zobowiązały się do wspierania organizacji prowadzonych przez mniejszość niemiecką ${ }^{40}$.

W podobnym tonie sporządzono Umowę między Republiką Słowacką a Ukrainą o dobrym sąsiedztwie, przyjaznych stosunkach i współpracy z 29 VI 1993 r. (Zmluva medzi Slovenskou a Ukrajinou o dobrom susedstve, priatel'ských vztahoch a spolupráci). Strony zapewniły członkom mniejszości prawo do zachowania swojej kultury, tożsamości oraz wyznania „W warunkach pełnej równości wobec prawa”41. Ponadto zobowiązano się do stworzenia warunków umożliwiających prowadzenie nauki, nauczania języka ojczystego oraz swobodnego posługiwania się nim, a także zakładania stowarzyszeń edukacyjnych, kulturalnych i religijnych. Władze Słowacji i Ukrainy zezwoliły również na uczestnictwo w pracach międzynarodowych organizacji pozarządowych ${ }^{42}$.

Słowacja jest także stroną dokumentów wielostronnych, a przykładem może być Konwencja ramowa o ochronie mniejszości narodowych (Rámcový dohovor na ochranu národnostných menšín). Konwencja została podpisana 1 II 1995 r. i weszła w życie 1 II 1998 r. $^{43}$. Należy podkreślić, iż państwa-strony otrzymały pewną swobodę w realizowaniu zapisów umowy ${ }^{44}$.

Kolejnym multilateralnym dokumentem podpisanym przez Bratysławę jest Europejska karta języków regionalnych lub mniejszościowych Rady Europy (Európska charta regionálnych alebo menšinových jazykov Rady Európy). Dokumenty ratyfikacyjne zostały złożone 5 IX 2001 r., a zapisy Karty weszły w życie 1 I 2002 r. ${ }^{45}$. Władze Słowacji zadeklarowały, że językami chronionymi są: bułgarski, czeski, chorwacki, węgierski, niemiecki, polski, romski, rusiński i ukraiński.

-a-spolkovou-republikou-nemecko-o-dobrom-susedstve-a-priatelskej-spolupraci/sdeleni-c-521-1992-zb-o-zmluve-medzi-ceskou-a-slovenskou-federativnou-republikou-a-spolkovou-republikou-nemecko-o-dobrom-susedstve-a-priatelskej-spolupraci (14 VII 2021).

$40 \quad$ Ibidem.

${ }^{41}$ Zmluva medzi Slovenskou a Ukrajinou o dobrom susedstve, priatelských vztahoch a spolupráci, https://www.aspi.sk/products/lawText/1/42100/1/2/oznamenie-c-177-1994-zz-o-zmluve-medzi-slovenskou-republikou-a-ukrajinou-o-dobrom-susedstve-priatelskych-vztahoch-a-spolupraci/oznamenie-c-177-1994-zz-o-zmluve-medzi-slovenskou-republikou-a-ukrajinou-o-dobrom-susedstve-priatelskych-vztahoch-a-spolupraci (14 VII 2021).

42 Ibidem.

43 Rámcový dohovor na ochranu národnostných menšín, https://www.slov-lex.sk/pravne-predpisy/SK/ZZ/1998/160/19980604 (24 VI 2021).

44 Mniejszości narodowe i etniczne, Ministerstwo Spraw Wewnętrznych i Administracji, http:// mniejszosci.narodowe.mswia.gov.pl/mne/prawo/konwencja-ramowa-rady/konwencja-ramowa-rady/6769, Raport-wyjasniajacy-do-Konwencji-ramowej-Rady-Europy-o-ochronie-mniejszosci-naro.html (15 VII 2021).

45 Európska charta regionálnych alebo menšinových jazykov Rady Európy 588/2001 Z. z., https:// www.slov-lex.sk/pravne-predpisy/SK/ZZ/2001/588/20011229 (15 VII 2021). 
Jak podkreślają Radosław Zenderowski oraz Piotr Bajda, najsilniej chronionym językiem został język węgierski: „Jego ochronę oparto na 53 ustępach lub punktach III części Karty (minimalna liczba ratyfikowanych ustępów lub punktów wynosi 35$)^{\prime 46}$. Słowackie władze zobowiązały się m.in. do zapewnienia edukacji w języku węgierskim na wszystkich poziomach, tj. od przedszkolnego do uniwersyteckiego, posługiwania się językiem węgierskim w sądach, administracji, radiu i telewizji, a także zapewniły pismom administracyjnym sporządzonym w języku węgierskim taką samą ważność, jak dokumentom spisanym w języku słowackim.

\section{Analiza rozwiązań prawnych wprowadzonych na Słowacji}

Słowacja nie zawsze wprowadzała rozwiązania sprzyjające mniejszościom narodowym, a dowodem tego są regulacje prawne wdrożone przez ówczesne władze w latach 90. ubiegłego stulecia. Słowackie prawo krytykowali zarówno członkowie mniejszości zamieszkujący teren Republiki, jak i kraje ościenne (głównie Węgry) oraz Unia Europejska. Szczególnie niezadowolenie wywołała przyjęta w 1995 r. przez rząd Vladimíra Mečiara ustawa o języku państwowym. Zgodnie z jej postanowieniami, język słowacki uzyskał pierwszeństwo przed innymi językami używanymi na terenie kraju, a członkowie mniejszości nie otrzymali prawa do posługiwania się swoimi językami m.in. w kontaktach urzędowych oraz w szkolnictwie. Pomimo zapewnień premiera Mečiara o stworzeniu aktu regulującego posługiwanie się językami mniejszości, w pierwszych latach suwerenności słowackim władzom nie udało się przyjąć owej ustawy - jak już wcześniej wspomniano, nastąpiło to dopiero w $1999 \mathrm{r}^{47}$. Następnym przykładem rozwiązań prawnych pogarszających położenie przedstawicieli mniejszości narodowych (przede wszystkim aktywnej politycznie społeczności węgierskiej) była zmiana w ordynacji wyborczej przeprowadzona w marcu 1998 r. Zgodnie z nowymi zapisami, każda partia musiała przekroczyć 5\% próg wyborczy, niezależnie od tego, czy startowała sama, czy wchodziła w skład koalicji. Nowelizacja ustawy sprawiła, że działające dotąd oddzielne węgierskie ugrupowania zostały zmuszone do utworzenia wspólnej partii, tak aby nadal mieć realny wpływ na sytuację polityczną w kraju ${ }^{48}$.

Szansa na poprawę sytuacji mniejszości narodowych pojawiła się w 1998 r., gdy na czele nowego gabinetu stanął Mikuláš Dzurinda. O konieczności przeprowadzenia stosownych zmian apelowali przedstawiciele Komisji Europejskiej.

$46 \quad$ R. Zenderowski, P. Bajda, op.cit., s. 443.

47 E. Pałka, Problematyka mniejszości narodowych na Słowacji, [w:] Współczesna Słowacja. Sytuacja wewnętrzna i pozycja międzynarodowa, red. E. Pałka, Wrocław 2010, s. 215.

48 P. Sula, Partie małe w wybranych państwach Europy Środkowo-Wschodniej w latach 1989-2016, Kraków 2018, s. 111. 
W raporcie z oceny postępów przygotowań Bratysławy do uzyskania członkostwa w UE z 1998 r. odnotowano, że „nowy rząd ma teraz szansę na to, by okazać swoje przywiązanie do zasad demokratycznych oraz poszanowania praw człowieka i rządów prawa" ${ }^{49}$. W dokumencie zwrócono uwagę na potrzebę zmian przepisów zawartych w ustawie o języku państwowym oraz konieczność wprowadzenia aktu regulującego posługiwanie się językami mniejszości narodowych - ten został przyjęty w 1999 r. i dzięki niemu Słowacja spełniła Kryteria kopenhaskie ${ }^{50}$.

Od lat kwestią sporną pozostaje także zapis w preambule słowackiej konstytucji, który pomija przedstawicieli mniejszości narodowych, a sam naród traktuje w kategoriach etnicznych. Ów zapis brzmi: „My, naród słowacki” ${ }^{51}$. Ponadto, jak zauważa Elżbieta Szyszlak, kolejnym zarzutem wobec ustawy zasadniczej jest fakt, iż „nie zabezpiecza w dostatecznym stopniu możliwości kształcenia w językach mniejszościowych" ${ }^{52}$. Kolejnym rozwiązaniem prawnym uderzającym w mniejszości narodowe jest zakaz posiadania podwójnego obywatelstwa. Przepis ten został wprowadzony w $2010 \mathrm{r}$. i był odpowiedzią na znowelizowaną przez rząd Viktora Orbána ustawę o nadawaniu węgierskiego obywatelstwa - od tego momentu osoby przyjmujące obywatelstwo innego kraju automatycznie tracily obywatelstwo słowackie. W 2020 r. pojawiła się jednak szansa na zmianę przepisów, ponieważ premier Igor Matovič zapowiedział zniesienie ustawy wprowadzonej przez swojego poprzednika ${ }^{53}$.

\section{Zakończenie}

Analiza rozwiązań prawnych oraz instytucji regulujących położenie mniejszości narodowych na terenie Słowacji pozwala stwierdzić, iż władze Bratysławy na przestrzeni lat wypracowały system ich ochrony, który możemy zaobserwować w innych państwach Europy Zachodniej lub Środkowej. Duża liczba ustaw oraz instytucji, które słowackie władze powołały po 1992 r. były podyktowane dążeniami Bratysławy do członkostwa w struktura zachodnich, głównie w Radzie Europy oraz Unii Europejskiej. Znaczący wpływ na rozwój legislatywy w tym obszarze miały także znajdujące się na terenie kraju mniejszości narodowe, a wśród nich najliczniejsza społeczność węgierska, która zwłaszcza w latach 90. ubiegłego stulecia głośno domagała się nowelizacji niektórych ustaw.

49 M. Brosig, The challenge of implementing minority rights in Central Eastern Europe, „European Integration" 2010, vol. 32, $\mathrm{nr}$ 4, s. 398.

50 Ibidem.

51 E. Harris, Moving politics beyond the state: the Hungarian minority in Slovakia, „Perspectives. The Central European Review of International Affairs" 2007, nr 28, s. 51.

52 E. Pałka, op.cit., s. 214.

53 V. Jóźwiak, Pamięć i polityka - znaczenie Trianon dla Wegier, „Biuletyn PISM”, nr 117 (2049), s. 2. 


\section{Abstract \\ Aleksandra Puzyniak \\ The legal status of national minorities in the Slovak Republic}

The location of national minorities in the territory of the Slovak Republic is regulated by numerous national acts, the most important of which are the constitution, the law on the use of national minority languages and the law on the state language. References to national minorities can be found in many other acts, such as the Act on counteracting discrimination, the Act on Upbringing and Education and the Act on Radio and Television. The issue of minorities is also raised in bilateral agreements, an example of which is the agreement on good neighbourliness and friendly cooperation between the Slovak Republic and the Republic of Hungary. The legal situation of minorities in Slovakia is also influenced by international organizations to which Bratislava belongs. In this case, the Council of Europe's most significant influence, the European Union, the Central European Initiative and the United Nations. Over the years, the Slovak authorities have also created institutions responsible for activities for national minorities, and among them, an important function is performed by the Government Plenipotentiary of the Slovak Republic for National Minorities.

This article aims to analyse the legal acts and institutions regulating the legal status of national minorities in Slovakia. The publication is also intended to show that the issue of minorities is covered in many legal solutions, and the Slovak authorities have developed a system of protection and support for this community over the years. The author used the institutional and legal method.

Keywords: Slovakia, national minorities, legislation, internal law, international agreements

\section{References}

Bajda, P., Zenderowski, R., Polityka etniczna Stowacji, Warszawa 2016.

Brosig, M., The challenge of implementing minority rights in Central Eastern Europe, „European Integration” 2010, vol. 32, nr 4.

Európska charta regionálnych alebo menšinových jazykov Rady Európy 588/2001

Z. $z$, https://www.slov-lex.sk/pravne-predpisy/SK/ZZ/2001/588/20011229.

Harris, E., Moving politics beyond the state: the Hungarian minority in Slovakia, „Perspectives. The Central European Review of International Affairs" 2007, nr 28. 
Jóźwiak, V., Pamięć i polityka - znaczenie Trianon dla Węgier, „Biuletyn PISM”, nr 117 (2049).

Konstytucja Republiki Słowackiej z 1 IX 1992 r., tłum. K. Skotnicki, http://biblioteka.sejm.gov.pl/wp-content/uploads/2016/11/Slowacja_pol_010711.pdf.

Mniejszości narodowe i etniczne, Ministerstwo Spraw Wewnętrznych i Administracji, http://mniejszosci.narodowe.mswia.gov.pl/mne/prawo/konwencja-ramowa-rady/konwencja-ramowa-rady/6769, Raport-wyjasniajacy-do-Konwencji-ramowej-Rady-Europy-o-ochronie-mniejszosci-naro.html.

Pałka, E., Problematyka mniejszości narodowych na Słowacji, [in:] Współczesna Słowacja. Sytuacja wewnętrzna i pozycja międzynarodowa, ed. E. Pałka, Wrocław 2010.

Rámcový dohovor na ochranu národnostných menšin, https://www.slov-lex.sk/ pravne-predpisy/SK/ZZ/1998/160/19980604.

Sula, P., Partie małe w wybranych państwach Europy Środkowo-Wschodniej w latach 1989-2016, Kraków 2018.

Układ między Rzecząpospolita Polska a Czeską i Słowacją Republika Federacyjna o dobrym sąsiedztwie, solidarności i przyjacielskiej wspólpracy, http://isap. sejm.gov.pl/isap.nsf/download.xsp/WDU19920590296/O/D19920296.pdf.

Zákon Národnej rady Slovenskej republiky o štátnom jazyku Slovenskej republiky, https://www.zakonypreludi.sk/zz/1995-270.

Zákon o používaní jazykov národnostných menšín, https://www.slov-lex.sk/pravne-predpisy/SK/ZZ/1999/184.

Zákon o Rozhlase a televízii Slovenska, https://www.zakonypreludi.sk/zz/2010- 532.

Zákon o rovnakom zaobchádzaní $v$ niektorých oblastiach a o ochrane pred diskrimináciou a o zmene a doplnení niektorých zákonov (antidiskriminačný zakon), https://www.slov-lex.sk/pravne-predpisy/SK/ZZ/2004/365/20160102.

Zákon o výchove a vzdelávaní (školský zákon) a o zmene a doplnení niektorých zákonov, https://www.slov-lex.sk/pravne-predpisy/SK/ZZ/2008/245/.

Zenderowski, R., Bajda, P., Polityka etniczna Słowacji, [in:] Polityka etniczna współczesnych państw Europy Środkowo-Wschodniej, eds. H. Chałupczak, R. Zenderowski, W. Baluk, Lublin 2015.

Zmluva o dobrom susedstve a priatelskej spolupráci medzi Madiarskou republikou a Slovenskou republikou, https://www.aspi.sk/products/lawText/1/45399/1/2/ oznamenie-c-115-1997-zz-o-uzavreti-zmluvy-o-dobrom-susedstve-a-priatelskej-spolupraci-medzi-slovenskou-republikou-a-madarskou-republikou/ oznamenie-c-115-1997-zz-o-uzavreti-zmluvy-o-dobrom-susedstve-a-priatelskej-spolupraci-medzi-slovenskou-republikou-a-madarskou-republikou.

Zmluva medzi Českou a Slovenskou Federatívnou Republikou a Spolkovou republikou Nemecko a dobrom susedstve a a priatel'skej spolupráci, https://www.aspi. sk/products/lawText/1/40295/1/2/sdeleni-c-521-1992-zb-o-zmluve-medzi-ceskou-a-slovenskou-federativnou-republikou-a-spolkovou-republikou-nemec- 
ko-o-dobrom-susedstve-a-priatelskej-spolupraci/sdeleni-c-521-1992-zb-o-zmluve-medzi-ceskou-a-slovenskou-federativnou-republikou-a-spolkovou-republikou-nemecko-o-dobrom-susedstve-a-priatelskej-spolupraci.

Zmluva medzi Slovenskou a Ukrajinou o dobrom susedstve, priatelských vztahoch a spolupráci, https://www.aspi.sk/products/lawText/1/42100/1/2/oznameniec-177-1994-zz-o-zmluve-medzi-slovenskou-republikou-a-ukrajinou-o-dobro m-susedstve-priatelskych-vztahoch-a-spolupraci/oznamenie-c-177-1994-zz-o-zmluve-medzi-slovenskou-republikou-a-ukrajinou-o-dobrom-susedstve-priatelskych-vztahoch-a-spolupraci.

Aleksandra Puzyniak - mgr stosunków międzynarodowych, doktorantka w Zakładzie Badań Wschodnich w Instytucie Studiów Międzynarodowych Uniwersytetu Wrocławskiego. ORCID: 0000-0002-6969-4632 